\title{
The Use of Relationship Marketing in Developing Network and Co- operative links within Tourism Product Marketing Groups (PMG's
}

Catherine Gorman

Technological University Dublin, catherine.gorman@tudublin.ie

Follow this and additional works at: https://arrow.tudublin.ie/tfschhmtbook

Part of the Human Geography Commons, and the Marketing Commons

\section{Recommended Citation}

Gorman, C. (2006) Chap 10. The Use of Relationship Marketing in Developing Network and Co-operative links within Tourism Product Marketing Groups (PMG's) pp. 149-169 in Tourism Local Systems and Networking eds. Lazzeretti, L. and Petrillo, C. pub. Elsevier

This Book Chapter is brought to you for free and open access by the School of Tourism \& Hospitality Management at ARROW@TU Dublin. It has been accepted for inclusion in Books / Book chapters by an authorized administrator of ARROW@TU Dublin. For more information, please contact arrow.admin@tudublin.ie, aisling.coyne@tudublin.ie, gerard.connolly@tudublin.ie.

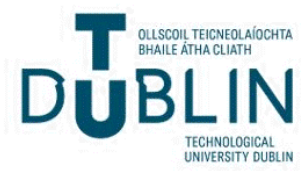




\section{The Use of Relationship Marketing in Developing Network and Co-operative links within Tourism Product Marketing Groups (PMG's)}

Catherine Gorman B.Sc M.Appl.Sc. MBS, MMII

School of Hospitality and Tourism Management

Dublin Institute of Technology (DIT),

Cathal Brugha Street,

Dublin 1

Republic of Ireland

Email: catherine.gorman@dit.ie

Catherine Gorman lectures in tourism, marketing and product development at DIT. Catherine has worked as a practitioner and an academic in the tourism industry in Ireland for the past fifteen years. Catherine has been involved in development and marketing of the tourism at local, regional and national levels. She is at present involved in an EU funded Interreg IIIA project on partnership and networking in tourism in co-operation with Trinity College Carmarthen, Wales and is pursuing a $\mathrm{PhD}$ through the Department of Geography, Trinity College, Dublin. Catherine has contributed papers and chapters on a number of tourism related topics such as tourism marketing and co-operation, tourist attractions and rural tourism. At present her interests are in the use of relationship marketing and networking in tourism, product development and ecotourism 


\section{Abstract}

Co-operative marketing groups are common in tourism, particularly in the case of destination marketing. Destination tourism marketing groups offer a diverse range of tourism products and experiences which complement each other and are delineated by a specific geographical parameter. Tourism product marketing groups offer similar tourism products or services and through a co-operative approach focus on an identified target markets. Cooperative marketing can make greater impact in terms of market presence and can be more cost effective. Members need to see the value in their membership in order to remain involved. Many tourism product providers are SMTE's (Small and Medium Tourism Enterprises) and as tourism is recognised as a fragmented business, peripherality may play a role in isolating some providers. Co-operative marketing and evolving relationships can help to create a common group identity and a sense of belonging.

Socio cultural issues, evaluation of product vision, perceived value as well as many of the constructs associated with the concepts of co-operative marketing, networking and relationship marketing, are explored with a view to understanding a more effective and efficient method of product marketing.

\section{Keywords}

Co-operative marketing, networking, relationship marketing, product marketing groups 


\section{Introduction}

Tourism in the Republic of Ireland has seen a considerable increase in the recent past with a doubling of overseas visitor numbers and more than doubling of total foreign tourism revenue in the period $1990-2003$.

INSERT TABLE 1

In 2002, there were 140,000 people employed in the tourism sector in the Republic of Ireland. The industry is considered to be one of the most financially important industries within the state, and contributes significantly to the gross national product. This growth in the industry has been due to a number of factors. The allocation of significant funding from the European Union initially led to the investment in and development of the tourism product. Subsequent investment in marketing in the sector has helped the industry gain a competitive advantage which is recognized by its annual growth during this period. More recently, due to a number of internal and external factors including increased competition from other destinations, the perceived high cost economy and increased mobility by consumers has seen an erosion of this competitiveness. This has led to a greater need to become more market oriented particularly with a focus on identified market demand with respect to the product and industry players have generally developed a more strategic approach to the marketing of their products. A reorganization of the structure of the statutory bodies within the industry (Bord Failte and CERT) in 2002 led to the creation of Tourism Ireland Limited (TIL) and Failte Ireland. Tourism Ireland Limited has sole responsibility for the marketing of the industry within both the Republic and Northern Ireland internationally and Failte Ireland is the domestic arm of the organization and has responsibility for servicing, training, product development and domestic marketing.

During the 1980's and 1990's, the availability of funding allowed the statutory bodies to develop a strategy that would develop an attractive product suited to both the resources of the country and to the expected demands of the international visitor. One of the resources that was recognized as being important to tourism were gardens. Gardens have played a 
significant role in the tourism product in other countries such as Great Britain, Italy and France and although they are transient in nature, they are often linked to features of heritage such as great houses and attract a significant number of visitors. Due to the diversity of geology, mild climate, geomorphic and social history, many gardens have been created throughout Ireland over time. The art of gardening arrived to Ireland with Christianity about 500AD with monks developing gardens which focused on the cultivation of vegetables for food. In 1620, Lismore, County Waterford was created and is one of the earliest formal gardens which still survives to some extent in its original form. The French, Dutch and English all had considerable influence over the subsequent centuries in garden design and development which resulted in numerous gardens. The introduction of many plants from around the world to these gardens were as a result of plant hunting expeditions undertaken particularly in Australasia during the nineteenth and early twentieth centuries (Lamb and Bowe 1995). Today, many of these gardens are part of a tourism product marketing group called Houses, Castles and Gardens of Ireland (www.castlesireland.com). This group which is simply structured requires the payment of a membership fee which goes towards the employment of a part time marketing executive and co-operative marketing activities. The decision on which activities to pursue, is made by a board of voluntary non executive members all whom are part of the group. A representative from the Irish tourism board (Failte Ireland) also sits on the board and they meet once per month. Numerous interactions in the form of relationships building, networking, and co-operative practices take place between the members of the group and between the members and external stakeholders. These webs of network interaction and relationships exist, developed to a greater extent by some gardens over others

Gardens have been identified as being of significant importance to the heritage of Ireland, and as well as there being an identified market demand for such a product, this resource closely fits the image Ireland wishes to portray in the international tourism arena. Gardens attracted 438,000 overseas visitors in the Republic of Ireland in 2001 (Bord Failte 2002). During the 1990's under the Operational Programme for Tourism, many of the gardens in Ireland availed of substantial funding through the Great Gardens of Ireland Restoration Scheme which was administered between 
1996 and 2001 (Gorman and Reid 2000). A dedicated manager, Ms. Finola Reid oversaw the management of this particular scheme.

In the mid 1980's tourism product marketing groups were initiated in the Republic of Ireland with a focus on activities and leisure pursuits. It was during a time that just preceded the rapid growth in overseas tourist numbers to the country and this co-operative marketing approach was part of an overall marketing strategy undertaken by the national tourism board (Bord Failte). In the accommodation sector in Ireland, common product groups have been in operation since the mid 1960's when Irish Farmhouse Holidays was set up to promote Irish Farmhouse accommodation to the visitor. The organization successfully operates alongside Town and Country Houses and the Irish Hotel Federation (IHF) as the main bodies promoting serviced accommodation in the Republic of Ireland.

The Product Marketing Groups (PMG's) focused on bringing together of a number of Small and Medium Tourism Enterprises (SMTE's) in identified sectors of the industry who offered a common core product to the visitor. The Gardens of Ireland was one of the first such Product Marketing Groups and this was facilitated by Mary Nash of Bord Failte - the Irish Tourist Board of the time.

This chapter attempts to answer a number of questions that surround PMG's. These include:

- the extent and type of co-operation and relationships undertaken by tourism product marketing groups - this includes both inter and intra organisational relationships undertaken by members of a PMG

- the type of marketing strategy and tactics utilised by members of a tourism PMG - considered in order to evaluate the type and degree of tools associated with relationship marketing that is being used by each group member;

- the consideration of the importance of value of the product; benefits and barriers in developing co-operative links

- an investigation into a number of variables which may have an impact on co-operation such as geographical loci, experience, qualifications, history and background of the development and maintenance of relationships within a marketing co-operative group. 
The significance of the research is based on the fact that in order to be competitive, a strong marketing ethos is required within any organisation. $\mathrm{Li}$ and Nicholls (2000) state that in order to remain competitive, co-operation is required with a range of stakeholders. According to Buhalis and Cooper (1998), SMTE's (Small and Medium Tourism Enterprises) lack competitiveness. Many SMTE's are fragmented and lack structure either of the organisation or in the way business is undertaken. Since the 1980's in Ireland, many SMTE's have become involved to a lesser or greater degree with co-operative marketing bodies. Some of these co-operative bodies operate efficiently, some do not.

Being funding led rather than market led has caused a problem with some groups struggling as funding has run out. Other groups focus on market segmented areas and specific demand e.g. angling and walking. Many of the co-operative bodies are involved in various forms of relationship management which includes interaction with a variety of stakeholders including the traditional customer (visitor). Relationship marketing although advocated by the national tourism board (Bord Failte 1998) has been undertaken in many cases in an ad hoc rather than structured manner. A structured relationship oriented approach however, can help to create bonds and links between the group members and the various stakeholders.

Strong bonds, common vision, a structured approach and other variables are considered important to efficient networking. In identification of practises operating within a PMG, it is hoped that both best practise and deficits can be explored so that a more efficient and effective approach can be developed with a view to increase competitive advantage for SMTE's in this sector.

\section{Literature Review}

It is necessary due to the breadth of the topic area that three academic disciplines be explored. These included organisational theory incorporating network/co-operative/alliance/collaborative theory and authors such as Gray (1985, 1989), Grabher (1993) Stoel (2002); relationship marketing theory considering authors such as Gummesson, Gronoos, Christopher, Peck ((1990 - present) Kotler (1999), Carson et. al (1995) and co-operative theory focusing specifically on the tourism sector and work undertaken by authors 
such as Palmer (mid nineties-present), Morrison (1998), Drucke-Damonte (2000), Selin (2000), Jamel and Getz (1995), Caffyn (2000), Trembley (2000) had an input into the literature.

The definition of co-operation is based on that taken by Palmer (2002) as the 'bringing together of people and businesses to accomplish activities that would not otherwise be done'.

Parvatiyar and Sheth (1994) identify that relationship marketing is conducted through both a collaborative and co-operative effort. Kotler (2003) amongst others recognize that relationship marketing is only suitable where the long term value of the relationship is important enough or valuable to maintain. In the tourism sector this would mean relationships would be important to develop and maintain with some stakeholders such as competitors, suppliers (tour operators/tourist offices) the influence market (media) and local visitors rather than overseas visitors (tourist) who are considered the traditional customers of a tourist attraction. The relationship under investigation within this research include both dyadic and network relationships. Consideration is given to Gummessons approach to relationships (1999), whereby the focus of marketing goes from being marketing mix centric (4 P's) to networking centric (30R's). This approach includes the following relationships;

Customers, suppliers and competitors

Non market relationships

Nanorelationships

Morgan and Hunt (1994), in their seminal work termed the phrase ' cooperate to compete' and in their research considered closely the different relational exchanges that occur both internally and externally to an organization with the firm being central to all relationships that are undertaken.

\section{INSERT FIGURE 1}

Zueldin (1998) went a step further and termed the word 'co-opitition' whereby competitive firms collaborate to compete within a market. More recently, Gummesson (2002), recognized that relationships networks and interactions are core values of any business and that relationship marketing 
can now be defined as marketing based on the interactions within networks of relationships.

\section{Characteristics of Networking, Co-operative Marketing and Relationship Marketing}

Some of the similarities and dissimilarities of characteristics of each form of interaction are explored and are illustrated Figure 2. Those that are priority to each of the disciplines are considered separately under their disciplines. Those that are deemed to be common to each discipline are considered within the central zone. These are now discussed.

\section{INSERT FIGURE 2}

\section{Cohesiveness and Interdependence}

Palmer et al (2000) in researching co-operative marketing organisations identifies that the cohesiveness within a group over time is helped by a number of factors such as similarity of work, group size, threats from outside, leadership style and common social factors such as age, race and social status. Trembley (2000) identifies that economics has a part to play and that structures such as networks and partnerships allow high levels of interdependence and cohesiveness which provide an efficiency. He also suggests that networks are different from formal planning in the tourism sector as they involve continual investment in relationship capital. Grabher (1993) and Gray (1985) also recognize interdependence as an important factor to successful networking. Different forms of interdependence can occur: horizontal which was the most competitive form and members competing directly with each other for resources and the disposal of goods and services; vertical whereby different members act at different stages of production and symbiotic, where there is the least competition and organizations complement each other (Pennings in Hall (1991).

Common Vision and goal

Jamel and Getz (1995) in researching tourism planning and partnerships suggest the need to joint formulate a vision statement and tourism goals. As the nature of the industry is fragmented, there is a need to instigate methods 
that would help implementation, collaboration and facilitate consensus in order to achieve successful co-operation. The formation of a network may occur whereby there is a common vision of issues. The creation of any partnership arrangement requires vision and energy and is easier if the benefits are clearly seen (WTO 2003). Vision and goals need to be clearly articulated and transparent.

\section{Involvement}

Involvement and investment are part of any relationship and make up one of the key constructs discussed by Wilson (1993). To some degree this investment can be considered set along a continuum similar to that developed by Kotler (1996) whereby the relationship changes from being initially transactional through the stages to eventual partnership. Low involvement may cause ineffective relationships. A number of factors influence low levels of involvement and these are based on the value of the relationship to the stakeholder. Values can include utilitarian value, sign value - what the involvement indicates to others and pleasure value (Gordon et al (1998).

\section{Value}

Wilson (1993) discusses the concept of value within the relationship and develops it along three dimensions: behavioral which includes social bonding, trust and culture; strategic which considers goals, time to market, strategic fit and core competencies and economic with the inclusion of cost reduction and value engineering. In a study of behavioral analysis of cooperative marketing organizations, Palmer et al. (2000) saw a drift from business to social values as co-operation progressed over time. The production of a dynamic tends to be based on co-operation between firms who were at similar points within the value chain.

\section{Trust and Reciprocity}

Numerous authors have written about the importance of trust in relationship marketing (Morgan and Hunt 94; Berry 95) and invariably it is taken as given that trust is required to a greater or lesser degree in relationship formation and management.

Grabher (1993) identifies reciprocity whereby there is mutual exchange of information and interdependence with long term interaction leading to stability is an important element required for successful collaboration. Yau et al. (2000) also identifies reciprocity as a component of relationship marketing 
whereby it allows either party to provide favors for others within the relationship. Carson et al (1995) develops this well within the SME sector when considering the importance of the exchange of information which itself requires a degree of trust. The initial communication leads to an information exchange upon which trust is built over time and there may also evolve a social and personal bond. A social bond can compensate for financial costs of the relationship. As Donaldson and O'Toole (2002) suggest a successful relationship goes from being passive to active over time.

\section{Bonding and Socialization}

Levels of bonding within a relationship are important. Berry (1995) identifies three levels of bond within any relationship. These include price, social personalization and structural solutions. Whether the price be that which is offered to the traditional customer or that which is part of the cost of a co-operative membership creates a bond which forms a relationship and generates expectancy by the service/product provider. Personal socialization may develop over time. Sometimes a social bond may be there from the initial stages whereby a social similarity between stakeholders within a relationship exists e.g. social or educational class. Structural solutions bonding emerges from the bonds that are created through the organization and the agreed contract agreed by the active stakeholders within the group. Sharing of Resources

A sharing or combination of resources is a factor of unification in peripheral tourism organizations which enable effective marketing (Morrison 1998). Telfer in Laws (2002) describe the Canadian Tourism Commission Product Clubs (www.canadatourism.com) which have been established to combine resources in order to off set seasonality, increase diversity and be more competitive.

\section{Geographical Proximity}

This has been identified by Hall (1991) as an important factor in determining the level and frequency of interaction within an organization. Those who are geographically far apart may feel isolated, lack group identity and be less motivated to co-operate or network. More recently used technologies such as email and teleconferencing can help to offset the isolation felt by some members of a group. 


\section{Communication and marketing techniques}

The intensity of network communication and participation and the degree of integration is strategic to the decision making process. Convergence through communication exchange allows organizations to learn from each other (Tremblay 2000). The increased difficulty in finding the time to communicate with an increased number of people/stakeholders which is identified as part of relationship/network management process has impact on the ability to establish and maintain the necessary contacts to successfully network. The frequency of contact is important to establish and maintain a relationship with any stakeholder within a network in order to strengthen ties. The World Tourism Organization (WTO) (2003) advocate open and frequent communication to capitalize on the synergies at all stages of a partnership from its formation through to ongoing management. The correct timing and frequency of this communication is imperative to sustain commitment. Communication with all stake holders with in a network is important.

Cornell (04) investigates the way in which visitor obtain information indicating the effectiveness of tools used for marketing communication with visitors. She found that word of mouth (WOM) was by far the most important source $(83.4 \%)$ for information. This could be considered a referred personal approach which is dependant of visitor experience and product quality. She also found that the internet was the least important channel utilised for information with only $8.3 \%$ consulting the web. This may be a reflection of the older age group which has a propensity to visit this type of tourism product. Frequent flyer programmes and hotel loyalty schemes would be two of the most frequently used techniques used with in tourism co-operatives to foster and maintain relationships with customer (Garnham 1996).

\section{Group Identification and size}

Group identification and image are addressed by Stoel (2002) who saw group identification as an important factor to collaboration as well as frequency of communication. Group identification is defined by Kelly and Kelly (1994) as 'the desire of an individual to connect with other members'.Hall (1991)suggests that an increase in the number of organizations within a relationship affects dependences, domains, rewards and resources. Many ties 
may reduce the strength of each individual ties. Stoel (2002) suggests that the larger the group size, the weaker the group identification.

These are a number of issues that affect the interactions that are undertaken through the different types of relationships with a variety of stakeholders in tourism co-operative marketing and they gave direction to the questionnaire content which was administered as part of a semi structured interview to the garden owners/managers.

\section{Research Description and Methodology}

Due to the nature of the research subject, it was decided to undertake a qualitative approach to the methodology. The type employed is based on the philosophy of interpretivism and within this the phenomenological approach was used whereby the interviewer attempts to understand the situation from the interviewee's perspective. An inductive approach with theory building occurred as interviews were being conducted. There was an element of deduction as existing theory was used to guide the questions at interview stage. The facts that emerged and their associated values are interdependent. There was also linkage between researcher and the subject matter which led to a degree of both knowledge and involvement. The researcher had worked in the National Botanic Gardens for seven years in the mid to late 1980's and had been involved in a national organisation which included a number of the respondents. The researcher subsequently worked in tourism marketing and had sat as a regional representative on the chosen gardens element of the PMG - Gardens of Ireland in the early 1990's. Therefore both access and historical knowledge had a bearing on the methodology. This also contributed to the pre-understanding of the subject area and to the working paradigm (Gummesson 2000).

A basic conceptual framework was drawn up from the theoretical material (See Fig 3) and this together with experience in the area guided the question content used for the semi structured interview process.

INSERT FIG. 3

The method of a semi structured interview was used as 'they are a resource that reflects the interviewee's reality outside the interview (Seale 1999). Judd et al (1991) state that less structured interviews are used to obtain a more 
intrinsic study of perception, attitude, finding out basic issues, how people conceptualise a topic and their level of understanding. The mix of both structured questioning to obtain specific information and less structured questions was considered to be the best approach to this research.

Sampling was undertaken in a purposive manner with the chosen interviewees had to be or have been a member of a marketing co-operative with a focus on a single product area - in this case: gardens open as a tourist attraction. The choice to focus on those who were members of a national cooperative structure allowed membership at least at one stratum and possibly other strata such as local, regional and county co-operative groups. The members of Great Houses and Gardens of Ireland own or manage a garden which is considered a tourist attraction. As mentioned before, they pay an annual fee to employ a part time co-ordinator who markets and promotes the garden on their behalf.

Twenty five gardens were contacted with information being derived for 21 gardens. Prior to undertaking the interviews with the gardens, three interviews were undertaken with individuals who had a significant impact/input into the product marketing group. These included the marketing executive and the tourist board representative. The results of these interviews gave an insight into the function and operation of the PMG and aided with question refinement. The semi structured questionnaire administered individually to the garden owners/manager constituted of fifty questions and the interviews took between 1.5 and 3.5 hours to complete. The questions were a mix of open and closed questions and the use of Likert scaling in closed questioning gave direction to the answer and managed the research process. Prompts and aids were used with the main aid used being the Six Market Model based on Payne (1997). This was used when participants required help in identifying the contacts and relationships that they were involved in marketing the attraction. The lack of specific knowledge in this area was apparent from pre testing the interview and from general experience working within the SME tourism sector. The use of the model eased interviewee involvement. The Six Market Model was used as it has been successfully employed in over fifty organisations (Gummesson 1999).

Areas of interviews explored: 
- Non sensitive classified information

- Embedded issues such as history, length of time in ownership, occupation, qualifications and experience

- Perception of the product using a SWOT analysis

- Importance and benefits of the product including economic, social and the use of different marketing tools

- Issues related to co-operation within the group - contacts, relationship development, identification of essential characteristics for success/barriers to success

- The use of monitoring, auditing and market research

Administration did not include the use of a tape recorder. This decision was made for the researcher at the initial stages when the first respondent did not wish to be interviewed by tape. Hence the decision was made that all interviews would be undertaken without the use of a tape recorder. Although Silverman (2000) advocates the use of a tape recorder, Wolcott (2001) and Yin (1994) state that it is matter of preference. It was found that the interviewees were very frank and candid in their responses and subsequent testing using a tape recorder with a respondent showed a marked difference in response by an interviewee with no comment cited as a response to several questions. The non use of tape recorder was also used as a method of interview procurement in certain instances as it was emphasised that it was part of the confidential nature of the material.

In order to get the respondent to focus on the area in question in greater detail, the questions included the seeking of essential characteristics for successful co-operation in order to build a picture of the individual perception of the co-operative group.

Analysis started with the completion of the first interview. Three methods of analysis was utilised in thesis research based on Carson et al (2001). Axial coding identified the respondent. Selective coding identified themes that were common to the literature and this information was clustered using frequencies throughout the findings to provide material for discussion. The use of anecdotal evidence was used to illustrate certain points or extremes of viewpoint. 


\section{Summary of Findings and Discussion}

\section{Classified and embedded issues}

Most of the gardens were in private ownership $(n=14)$. This has significance as they do not receive state funding or support. All of those interviewed were either the manager or the owner/manager of the garden and no information apart from the general nature of the research was given to them prior to the interview. More than half of the respondents had no formal qualification in marketing, business or horticulture or were from a non related background and had therefore learnt 'on the job' $(n-=13)$. The gardens ranged in size from 2 acres to 160 acres and attracted between 500 and 380,000 visitors per annum indicating to the substantial difference in product type and capacity. The larger gardens tended to have additional or complementary facilities thus being attractive to a broader market which could include children/families, general day visitors, tour groups as well as specialist plant lovers. Values associated by the respondents with their garden product included 'freedom' 'tranquillity', peaceful' 'unique' and 'therapeutic'. Most of the gardens $(n=12)$ considered their gardens as specialist rather than general gardens indicating a perception of uniqueness. The variety of backgrounds and experiences would not contribute to the cohesiveness of the group - lack of a common ground ( Palmer 2000) and many of the them had a wide ranging perceptions and understanding of what values the gardens bought to the market.

There were 105 full time equivalents employed in the gardens $(n=21)$ though this did not include those employed in county councils, training schemes or students/summer placements. Conservation was the main reason for development and the opening of the garden to the public as minimal income was derived from the gardens with many citing a loss or minimal income $(\mathrm{n}=11)$. Only one garden which had significantly diversified its product reported a $50 \%$ contribution of the garden to its overall income. Marketing budgets ranged from the subscription of the PMG alone to $€ 80,000$ per annum with many $(n=10)$ allocating less than $€ 5,000$ per annum to marketing or were not aware of their marketing spend. The strengths, weaknesses, 
opportunities and threats of gardens as a tourism resource and product were discussed and are illustrated in Table 2.

\section{INSERT TABLE 2}

All respondents were members of the national co-operative marketing groups with a third not members of any other marketing groups. Other co-operative marketing group involvement included those at county, regional and local tourism/marketing levels.

The use and effectiveness are marketing tools was explored. All were or had been members of a co-operative marketing group with most finding it a very effective method of marketing $(n=13)$

Advertising and brochure production were the most common tools used $(n=15)$ though there was a mixed reaction to their effectiveness. Only third of the garden $(n=7)$ dealt with tour operators though some had tried this distribution channel with limited success. The size and capacity of some of the gardens would be a deterrent to working with the tour operator trade. Most of the respondents used the internet as marketing tool $(n=17)$ though al have a presence on the House, Castles and Gardens website. . There was mixed feedback in relation to its effectiveness and only a few $(n=3)$ citing it as a very effective tool. Other forms of tools used (not prompted) included word of mouth, signage and the use of marketing students.

\section{Co-operation and Relationships Marketing}

Respondents were asked of their thoughts on garden product marketing groups. Word association was asked for in the context of the phrase 'garden product marketing groups'. Five respondents indicated that either they had not thought about them or that they did not understand them. Other respondents used positive words or phrases such as 'a good idea', 'dedication', 'listen', 'should be effective', 'quality', 'communication' and 'togetherness'. Negative association included 'unfulfilled', 'poor', 'aging members', 'ineffective' and 'a lack of them'. 
Interviewees were asked to define the meaning of the word co-operation and the following results are shown in Table 3

\section{INSERT TABLE 3}

The definition of co-operation included 'helping each other' 'pooling resources' 'communication' with only one person citing a social element to co-operation or that fact that the group had similar products. This combination of resources and sharing is recognised in network unification by Morrison ( 1998). Much of the co-operation within this group involves joint promotion which is undertaken by an executive and the compilation and distribution of a joint brochure.

It can be seen that there is an understanding of co-operation, though this understanding varies from a product focus, to a human /social focus to a financial focus.

Values associated with co-operation focused on both information derivation and marketing. The need to seek information and to be in touch with what was going on spurred membership

The essential characteristics were sought in relation to co-operative marketing. Different words many of them commonly associated with a successful and efficient approach to co-operation were used. They included leadership, active co-operation, intelligence, focus, interest, ability to deal with people, image definition, commitment, enthusiasm, sharing, dynamic and the need for training and a marketing background. These characteristics concur with such work undertaken by the WTO (2003) and Tremblay (2000). During the exploration of this particular area, a number of issues in relation to their involvement with co-operative marketing groups were mentioned and these included geographical location and infighting within the co-operative structure. One respondent said that they 'did not have a clue' in relation to essential characteristics required for successful co-operative marketing. However, there seemed to be a general understanding of what cooperation was about, and many of the phrases/terms used to define characteristics are considered essential requirements to successful cooperation (Trust and 
commitment: Morgan and Hunt 94, Reciprocity; Saxena, 99, similar objectives; Palmer 00 and the importance of communication, Stoel 02)

\section{Relationship Building and Benefits}

There was a marked difference in relationship between those who had either been through some form of education/training in business/marketing experience and those who had neither a great deal of experience or knowledge of marketing. Some of the larger gardens and those that attracted a greater number of people had a strategic view with them citing the different markets without the use of the six market model and had a more planned and strategic approach to marketing.

INSERT TABLE 4

Marketing co-operatives $(n=10)$, and tourism organizations $(n=9)$ were the most common contacts undertaken by the respondents with tourist offices, friends and family and business associates being the least featured contacts $(n=3)$. The benefits of relationship building had not really been considered in many cases. Communication and frequency of communication between the garden owners /managers are other stakeholders were probed. Although the email was seen as an important support tool, it was the telephone and personal communication that was considered important by the more strategically minded gardens. Leaflet distribution between the gardens was also considered to be important. The development of a social element was mentioned by a number of the more successful gardens as an important factor though one garden mentioned that the members of the national co-operative had been broken down into cliques as 'there were some people that you got on better with than others'

These benefits of relationship development and contacts made included confidence building, creating and maintaining awareness, generating a good rapport, leaflet and brochure distribution, increase in visitor numbers and strengthening and building brand. However there were a number of negative responses such as 'I'm defeated by it all - there is so much jealously and begrudgery', 'I don't want to travel to Dublin to meetings' and ' there is no need to meet'. These may indicate a general lack of understanding of the 
work of the co-operative and the objectives of the group and show a lack of group vision and direction. Group and individual responsibility also seemed to be unclear in many circumstances - for example one respondent 'tour operators should contact you', though in relation to the co-operative marketing group, the same respondent stated' it is yourself who is important - only you can help yourself'.

The aim was to get the respondents to identify problems about relationships/ contact development without being too negative about one person or specific organisation. A number of respondents were positive 'no real problem,' ' no negatives except standards'. The standards as an issue is interesting to pursue, as it emerged through several of the interviews. A number of problems did emerge and these included 'a fragmented approach with a number of groups doing the same thing'. Quite a number of the respondents alluded to the ongoing disquiet within the co-operative marketing groups e.g. ' moaners wondering what they will get out of it' and 'many people seen as more important than others' and 'parochialism' on a county level. One respondent mentioned the important aspect of experience - those with experience vs. those without, and that this caused a problem in relation to the ability to develop contacts. One respondent suggested that 'the group was too large' and there was a lack of time to contact them all; however this respondent said that 'it was mainly beneficial'. Time appeared as an issue by several respondents. Co-operation was 'a good idea but nobody to do it'. Lack of trust was also mentioned by a respondent. Money was identified as an issue - 'some get caught up in the financial aspects and do not have time to market'. This can be seen more prevalently amongst those who are close to the garden, i.e. private /family owners who may be relying on the garden as a source of income.

In summary, perceived barriers to relationship development included the lack of time, the size of the garden, parochialism amongst the group and group dynamics.

Methods used to develop contacts/ develop relationships were sought as was frequency of contact. 'The creation of awareness and communication' was used as prompts if required. The responses ranged from the use of the usual marketing tools, such as brochures, familiarisations, better distribution etc to 
the need to be focused, creation of awareness through personal contact, creation of a bond, use of local co-coordinators and perseverance. Frequency ranged form once year or 'not a lot' to once per month, with much of the contact being undertaken in a personal manner i.e. by phone or meeting.

The thoughts of the respondents concerning co-operative marketing groups at the various different geographical levels, local, county, regional and national, were explored. No prompts were given here so as not to provoke a response in relation to a particular group. The general theme of each of the responses was considered and is shown in Figure 4.

\section{INSERT FIGURE 4}

One respondent who had studied co-operation in an academic context was wholly negative about the concept being used for the gardens as a tourist attraction as 'co-operatives and their structure attract altruistic people rather than business people'. The manager of the garden suggested that one should 'look at the underlying reasons why people join co-operatives', perhaps suggesting that there is a social rather than a business need. Palmer et al (2000) does state that this drift to a more social focus tends to occur as a cooperative relationship progress. This introduction of a social element may help to strengthen ties and increase cohesiveness making it more difficult to leave the group if there is an element of social equity tied up with the group. The manager did, however, believe that 'the co-operative model will work, but only if' there is continuous adherence to the co-operative principle and if the members have a serious commercial stake in the property'. A question has to asked whether at co-operative marketing structure is the most suitable method of marketing gardens as tourist attractions due to both the diversity of the product and the diversity of the values and vision of the owners/managers.

The garden managers/owners were generally more positive about national cooperative marketing groups though this is due to the fact that a third of them were only members of these groups and therefore could not make personal comment of the other strata of marketing co-operative group. There seemed to be little complaint in relation to geographical proximity the fact that it was 
a national organisation 'though it was recognised that core group of people did attend meetings and sometimes distance did prove a problem. Other elements tie this core together be it a passion for plants and gardens which was evident throughout many of the interviews.

The perceived value of both the product and of co-operative marketing groups was sought. This was done in an effort to establish whether there was commonality between the values perceived by the members. Most respondents applied the value concept of the product to their own garden and generally spoke of the tangibles, such as the plants and facilities, and the intangibles, such as ambience, space, tranquillity and sense of history. .

Additional comments were sought and overall the respondents were very positive about the interview. Some of them said that it had prompted them to think about what they were doing. Others were very interested in the results and all of the respondents have asked for feedback in some form or other.

\section{Conclusion and Future Issues}

A substantial amount of information has been gathered to date. This information has raised more questions than answers though there is agreement in many instances with the existing literature on co-operation and relationship development. Many on the respondents are involved in different elements of relationship marketing and management and though proactivity is limited in most cases particularly in relation to the tour operator trade The information shows that most of the members of the various co-operative marketing bodies are positive about their involvement. Are the levels of involvement, perceptions of value of the group similar and positive enough, and is there a significant amount of cooperation to develop effective group marketing and relationship marketing? It appears a basic framework does exist on which to base a relationship and truly co- operative stricture.

Thought and effort in relation to their involvement varies considerably from garden to garden. This is often linked to experience and training/ education in the area of management. Not all tools of communication were used by members and their usage linked either to knowledge of marketing, specific objectives in relation to garden visitors or desired level of involvement. Level of involvement is important to a relationship (Wilson 1993) and was 
impacted by geographical proximity to other members and to Dublin. Meetings do take place around the different gardens to allow each member an opportunity to the other gardens and to ease distance travelled.

Many of the respondents did not really identify with the group looking at it solely as a body to market the gardens overseas. Many could not cite a vision or objective. Group identification ( Stoel 2002) and vision (WTO 2003) are essential elements of successful co-operation The group in question is informal, loose, unstructured, spontaneous, with many of the members reactive confirming Gilmore et al ( 2001) definition of networking specifically in the SME sector. The lack of a structured approach by the members to relationship development whether within the group or with other stakeholders should reflects the need cited by Tremblay (2000) to continually invest in the process.

The research is presently being extended and a number of issues are being analysed in greater depth. This work is being conducted as part of a $\mathrm{PhD}$ which is being pursued through the Department of Geography, Trinity College Dublin. Other areas of research include an extension to other cooperative marketing groups both outside and within the garden sector to identify whether considering the different issues that are emerging. The issue of socialisation and its affect on levels of involvement could also be explored particularly in relation to gender difference. 


\section{Parnetourism: Partnerships, Co-operation and Networking in Tourism - A destination}

focus

A project entitled Parnetourism which is being funded under Interreg IIIA is presently being undertaken by the Tourism Research Centre, Dublin Institute of Technology and the Department of Geography, Trinity College, Carmarthen, Wales. The work focuses on product providers involved both directly and indirectly with the tourism industry in Counties Wexford and Carlow (Ireland), and Pembrokeshire and Carmarthen (Wales). The research which involves three stages and includes questionnaire completion, workshops and training seminars explores the idiosyncrasies of partnerships, co-operatives and networks in tourism destinations. Results from the quantitative phase were that the respondents considered that although marketing and networking were important advantages of group involvement, it was the wish to be part of the community that was seen as the greatest advantage. Meeting people and sharing ideas were also seen as advantages. Issues such as the lack of time, the lack of financial resources were noted as the main disadvantages as well as the fact that the same people undertake the work all of the time. The main reason why respondents tended to contact the group was to seek information with only one person mentioned the process of networking. However, the sharing of information is seen as a major contributor to networking. Contact tended to be on a monthly basis with the phone rivaling the popularity of the email as the method of communication.

Factors for successful networking included co-operation and communication, leadership and direction, with deterrents to success being a lack of involvement, lack of interest and lack of leadership. The reasons for involvement with a group was many, though having an asset and the seeking of information were the two most cited reasons why people became involved.

Work is presently being undertaken in evaluating information which is being derived qualitatively from the product providers and support bodies, which explore in greater depth the issues of group structure and size, involvement, communication used, performance and training. The project is due to be completed in November 2005. 
Figures to be inserted as indicated in text

Table 1

\begin{tabular}{|c|c|c|}
\hline & $\begin{array}{c}\text { Overseas Visitors } \\
\text { numbers (millions) }\end{array}$ & $\begin{array}{c}\text { Total Foreign Revenue } \\
\text { (Billions } € \text { ) }\end{array}$ \\
\hline 1990 & 3.0965 & 1.446 \\
\hline 2003 & 5.919 & 3.636 \\
\hline
\end{tabular}

Tourism Ireland 2004 
Table 2

A SWOT analysis of Irish Gardens as perceived by the owners/manager

\begin{tabular}{|l|l|}
\hline Strengths & $\begin{array}{l}\text { Climate, variety and diversity, history of the large house, range of } \\
\text { plants }\end{array}$ \\
\hline Weaknesses & $\begin{array}{l}\text { No weaknesses; don't market ourselves; attracts elderly visitors; } \\
\text { seasonality; roads and access }\end{array}$ \\
\hline Opportunities & $\begin{array}{l}\text { Tranquillity; local marketing; need to get Irish people to visit } \\
\text { gardens; packaging }\end{array}$ \\
\hline Threats & $\begin{array}{l}\text { Commercialisation; serious financial trouble; weather; lack of } \\
\text { interest; haven't the population in Ireland; fragmentation; price } \\
\text { transparency; staffing issues }\end{array}$ \\
\hline
\end{tabular}


Table 3 Frequency of words/ phrase used to define co-operation

\begin{tabular}{|l|c|l|c|}
\hline Words/Phrases Used & Frequency & Words/Phrases Used & Frequency \\
\hline $\begin{array}{l}\text { joint marketing } \\
\text { including } \\
\text { promotion/brochure }\end{array}$ & 8 & agreement & 2 \\
\hline helping each other & 5 & cost efficiency & 2 \\
\hline communication & 4 & similar products & 1 \\
\hline togetherness & 3 & common policy & 1 \\
\hline pooling resources & 2 & $\begin{array}{l}\text { getting to know each } \\
\text { other }\end{array}$ & 1 \\
\hline social & 1 & $\begin{array}{l}\text { something that should } \\
\text { be done in the future }\end{array}$ & 1 \\
\hline sharing & 1 & & \\
\hline
\end{tabular}


Table 4 Present relationship/contacts (Six Market Model shown as prompt)

\begin{tabular}{|l|c|l|c|}
\hline Relationship/Contact & Incidences & Relationship/Contact & Incidences \\
\hline Co-operatives & 10 & $\begin{array}{l}\text { Other } \\
\text { gardens/competitors }\end{array}$ & 4 \\
\hline Tourism organisations & 9 & Media & 4 \\
\hline $\begin{array}{l}\text { Other products } \\
\text { providers e.g. B\&B's. }\end{array}$ & 7 & Tour operators & 4 \\
\hline Suppliers & 7 & Business associates & 3 \\
\hline Customer & 6 & Tourist offices & 3 \\
\hline Employees & 5 & Friends/family & 3 \\
\hline
\end{tabular}




\section{Fig. 1 The Relational Exchanges in Relationship Marketing}

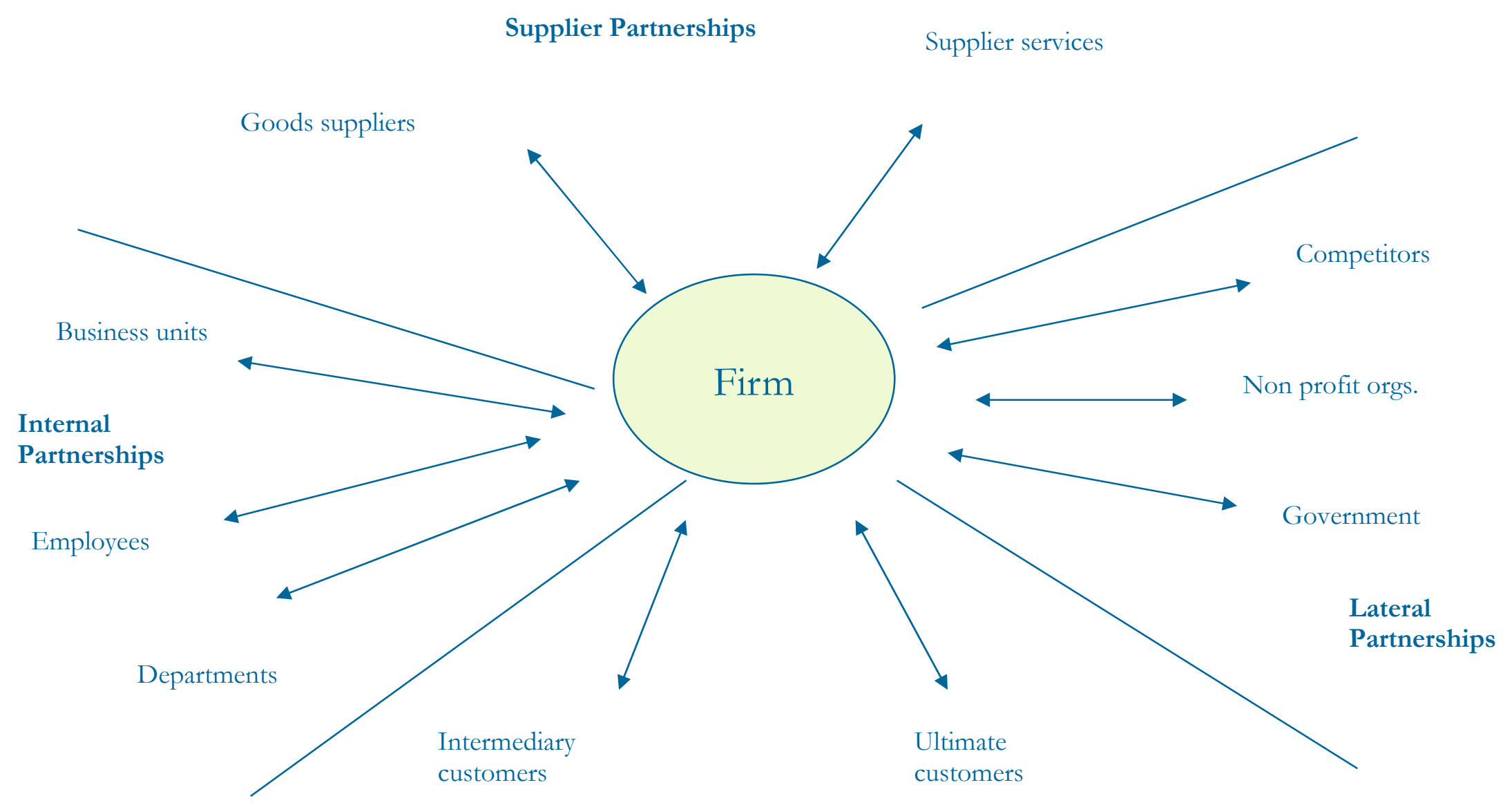

Buyer Partnerships

Based on Morgan and Hunt (1994) 


\section{Fig. 2 Characteristics of Relationship Marketing and Marketing Co-operation}

\section{Marketing Co-operation/networking}

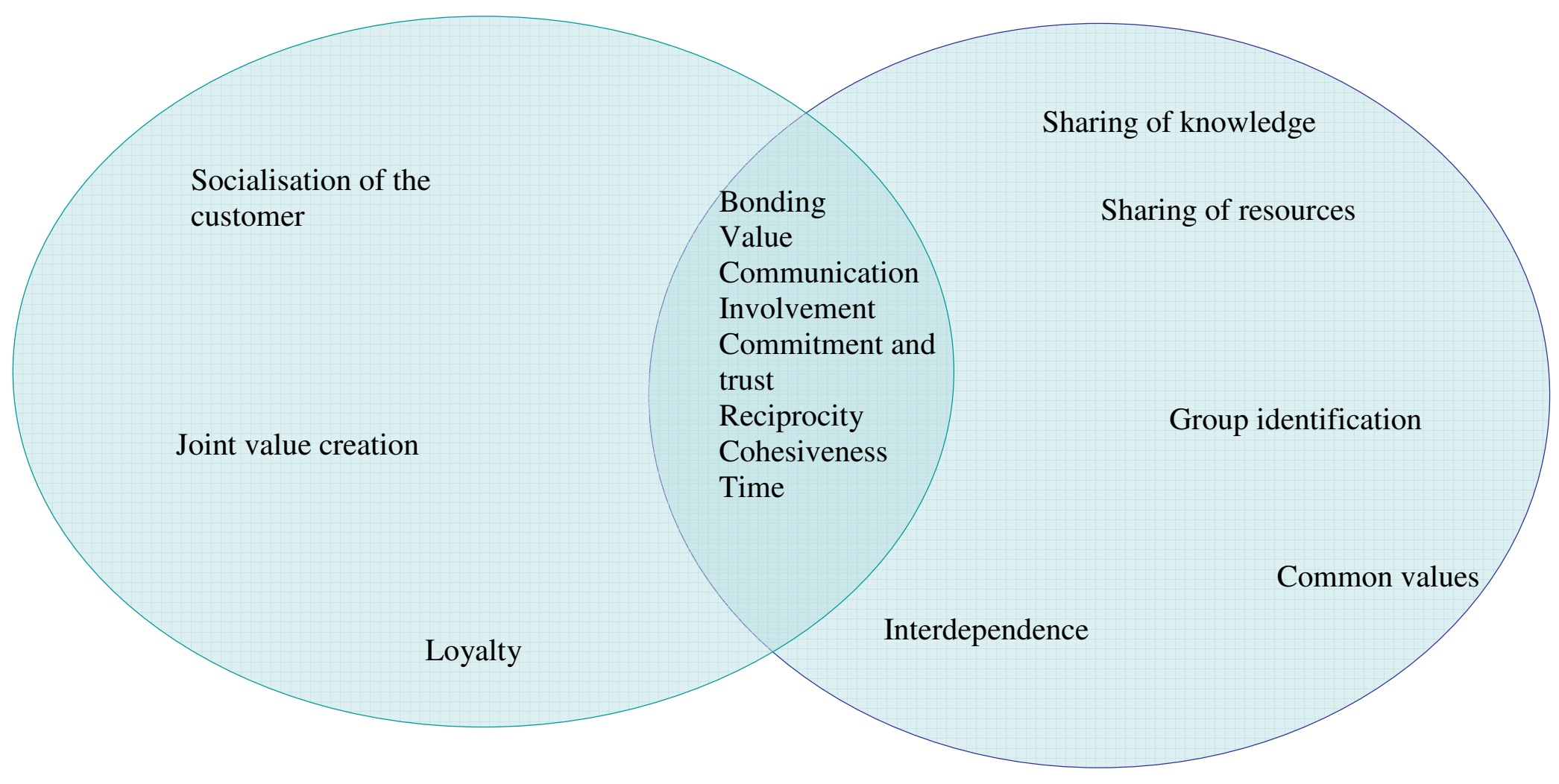

Relationship Marketing 
Fig. 3

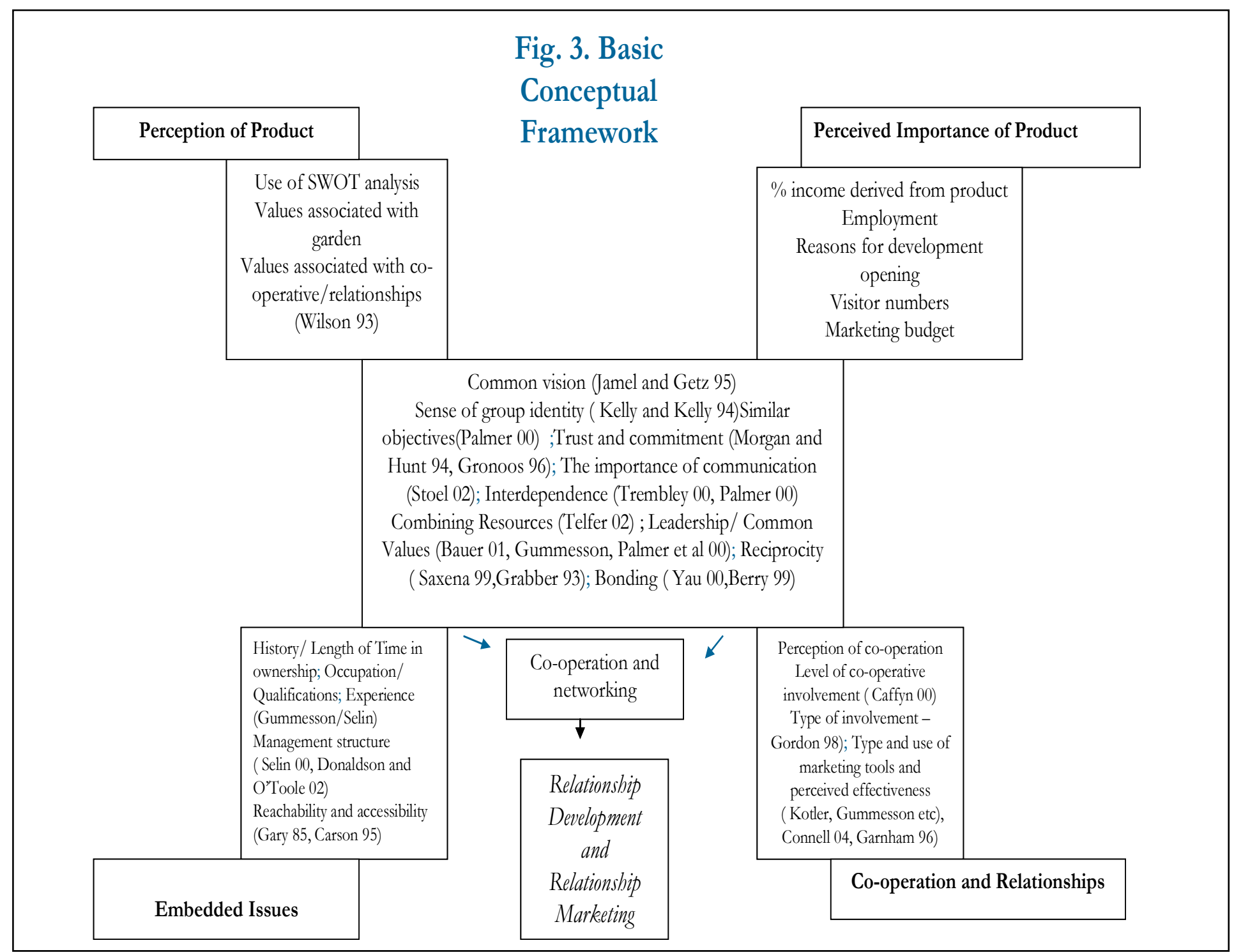




\section{Fig.4 Thoughts on Co-operative Marketing Groups}

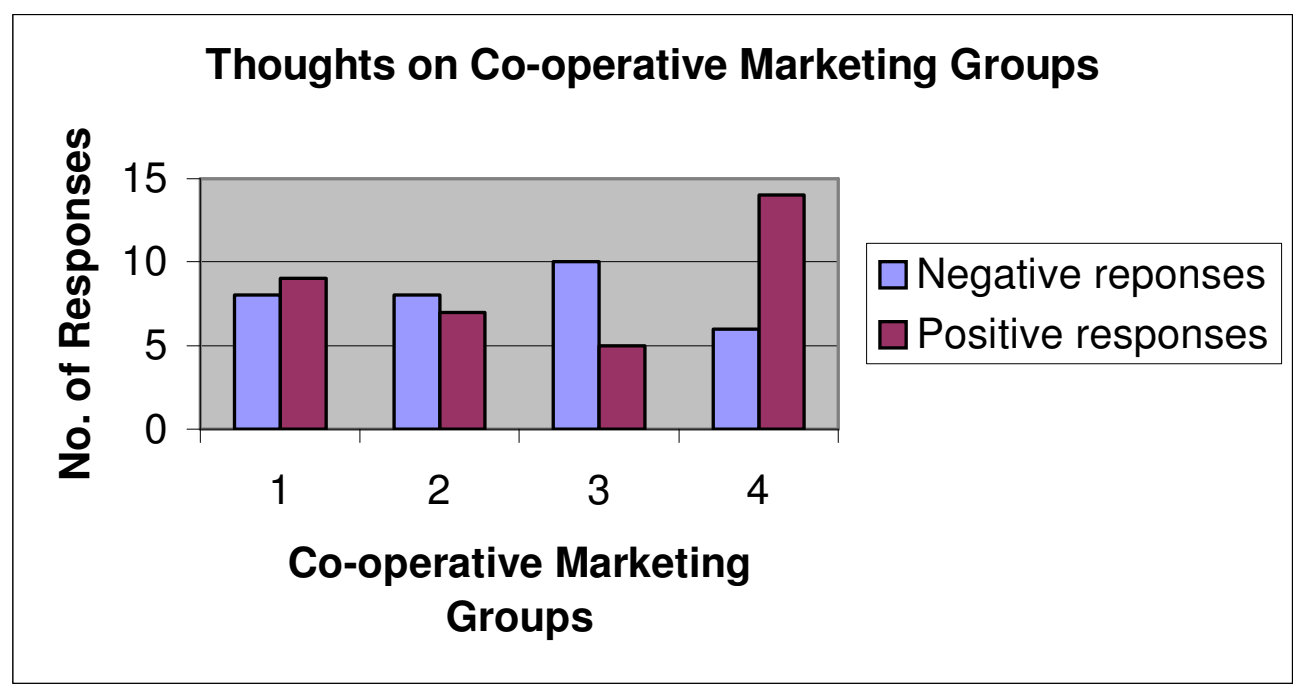

1. Local Co-operative Marketing Groups

2. County Co-operative Marketing Groups

3. Regional Co-operative Marketing Groups

4. National Co-operative Marketing Groups 


\section{References}

Berry, L. (1995) Relationship Marketing of Services - Growing Interest, Emerging Perspectives Journal of Academy of Marketing Sciences 23(4) pp 236245

Bord Failte (1998), Relationship Marketing pub Bord Failte Dublin Buhalis, D. and Cooper, C. (1998), Competition or Co-operation: SMTE at the Destination in Embracing and Managing Change in Tourism eds. Laws, E. Faulkner, B. and Moscardo, G. pub. Routledge

Caffyn, A. (2000) Is There a Tourism Partnership Lifecycle? In Bramwell, B. And Lane, B. (eds) (2000) Tourism Collaboration and Partnerships: Politics, Practise and Sustainability Clevedon: Channel View Publications

Carson, D, Cromie, S. McGowan, P. and Hill, J. (1995) Marketing and Entrepreneurship in SME's - An Innovative Approach pub. Prentice Hall Carson, D. Gilmore, A., Perry, C. and Gronhanig, K. (2001) Qualitative Marketing Research Pub. Sage 2001

Connell, J. (2004) The Purest of Human Pleasures: the Characteristics and Motivations of Garden Visitors in Great Britain Tourism Management 24. pp 229-247.

Donaldson, B and O'Toole, (2002) Strategic Market Relationships: From Strategy to Implementation pub. Wiley and Sons.

Drucke-Damonte, D. (2000) The Effect of Cross Industry Co-operation on Performance in the Airline Industry in Global Alliances in Tourism and Hospitality Management eds. Crotts, J. Buhalis, D. and March, R. pub. Haworth Press Inc.

Garnham, B. (1996) Alliances and Liaisons in Tourism: Concepts and Implications Tourism Economics 2

Gordon, M.E., McKeague, K. and Fox, M.A. (1998) Relationship Marketing Effectiveness: The Role of Involvement Psychology and Marketing August 1998 15(5) pp 443-459

Gorman, C. and Reid, F. ( 2000) Developing Ireland as a Successful Garden Tourism Destination in Ruddy, J. and Flanagan, S., Eds. 2000, Tourism Destination Marketing: Gaining the Competitive Edge, Dublin Institute of Technology, Tourism Research Centre. Pp. 437-443

Grabher, G. (1993) Rediscovering the social in the economics of interfirm 
relationships in Grabher, G.. ed. The Embedded firm on the Socioeconomics of Industrial Networks. Pub. Routledge London. pp 1-31.

Gray, B. (1985) Conditions facilitating Interorganisational Collaborations Human relations 38(10) pp911-936

Gray, B. (1989) Collaborating San Francisco, CA Pub. Joseph Bass. Gronoos, C. (1997) Value Driven Relational Marketing: From Products to Resources and Competencies. Journal of Marketing Management 13 pp 407-419. Gummesson, E. (1999) Total Relationship Marketing: Rethinking Marketing Management for the 4P's to the 30R's . Pub. Butterworth Heinemann Oxford UK Gummesson, E. (2000), Qualitative Methods in Management Research $2^{\text {nd }}$ Ed. Pub. Sage p. 60.

Gummesson, E. ( 2002) Relationship Marketing and the New Economy: Its Time for Deprogramming Journal of Services Marketing Vol 16(7).

Hall, R.H. (1991) Organizations: Structures, Processes and Outcomes $5^{\text {th }}$ Ed. Pub Prentice Hall. P. 227

Jamel, T.B. and Getz, D (1995) Collaborative Theory and Community Tourism Planning Annals of Tourism Research 22(1) pp186-204.

Judd, C., Smith, E. and Kidder, L. (1991) Research Methods in Social Relations pub. $6^{\text {th }}$ Edition.

Kelly, C. and Kelly, J. (1994) in Stoel (2002) Retail Co-operatives : group size, identification, communication, frequency and relationship effectiveness. International Journal of Retail and Distribution Management Vol. 30 No. 1.

Kotler, P. Marketing Management $11^{\text {th }}$ Ed. Pub. Prentice Hall p.660 Lamb, K. and Bowe, P. (1995) A History of Gardening in Ireland pub. The Stationary Office, for the National Botanic Gardens Glasnevin, Dublin. Li, F. and Nicholls, J. ( 2000) Transactional or Relationship Marketing Determinants of Strategic Choice Journal of Marketing Management 16 pp 449464

Morgan, R. And Hunt, S. (1994) Relationship Marketing in the Era of Network Competition, Marketing Management 3(1) pp 19-28

Morrison, A. (1998) Small Firm Co-operative Marketing in a Peripheral Tourism Region, International Journal of Contemporary Hospitality Management (10) 5 Palmer, A. (2001) The Evolution of an Idea: An Environmental Explanation of Relationship Marketing Journal of Relationship Marketing Palmer, A., Barrett, S. and Ponsonby, S. (2000) Behavioural Analysis of Co- 
operative Marketing Organisations Journal of Marketing Management Vol. 16 p273-290

Parvatiyar, A. and Sheth, J. ( 1994) Paradigm Shift in Marketing Theory and Approach - The Emergence of Relationship Marketing : Theory, Methods and Applications Section 1 Session 2.1 Eds. Sheth, J. and Parvatiayar, A Atlanta, GA Centre for Relationship Marketing , Emory University

Payne, A. (1997) Advances in Relationship Marketing, London: Cranfield Management Series pp. 31-38.

Payne, A. and Holt, S. (2001) Diagnosing Customer Value: Integrating the Value Process and Relationship Marketing British Academy of Management Vol. 12 pp159-182.

Seale, C. (1999) The Quality of Qualitative Research pub. Sage.

Selin, G.(2000) Developing a Typology of Sustainable Tourism Partnerships in

Tourism Collaboration and Partnerships eds. Bramwell, B. And Lane, B. pub.

Clevedon : Channel View Publications

Silverman, D. (2000) Doing Qualitative Research: A Practical Handbook pub. Sage Thousand Oaks, London. 2000.

Stoel, L. (2002) Retail Co-operatives: group size, identification, communication, frequency and relationship effectiveness International Journal of Retail and Distribution Management Vol. 30 No. 1. p. 149

Telfer, D. (2002) Canadian Tourism Commission Product Clubs in Laws, E.

Tourism Marketing 2002. pub. Continuum.

Tourism Ireland Limited (2004) Island of Ireland Overseas Visitors 2003

Tremblay, P. (2000) An Evolutionary Interpretation of the Role of Collaborative Partnerships in Sustainable Tourism in Tourism Collaboration and Partnerships eds. Bramwell, B. And Lane, B. Pub. Clevedon: Channel View Publications. Wilson, D.T et. al (1994) Understanding the Value of a Relationship Asia Australia Marketing Journal 2(1) pp55-66.

Wolcott, H. (2001) Writing Up Qualitative Research Sage Publications World Tourism Organizations ( 2003) Co-operation and Partnership in Tourism: A Global Perspective. pub. WTO, Madrid Yau, O. McFettridge, P. Chow, R. Lee, J. Sin, L and Tse, A. (2000) Is Relationship Marketing for Everyone European Journal of Marketing Vol. 34 No. 9/10 pp.1111-1127

Yin, R. (1994) Case Study Research Design and Methods. $3^{\text {rd }}$ Ed. pub. Sage 
Zueldin, M.A. (1998) Towards an Ecological Collaborative Relationship Management -A co-opitive perspective, European Journal of Marketing Vol. 32 No. 11/2. pp 1138-1164

\section{Websites}

www.castlesireland.com

www.canadatourism.com

www.tourismireland.com 